\title{
Textural diversity in selected Retisols in the catena of the Opalenica Plain (western Poland)
}

\begin{abstract}
The investigation was carried out in the catena of Retisols within the Opalenica Plain. The aim of the study was to characterize the variation in texture of selected Retisols formed from ground moraine glacial till of Leszno Phase of Vistulian glaciation. The analyzed soils are characterized by a similar degree of soil material segregation, which is characteristic for the typical glacial till. Particle size distribution and granulometric indices lead to conclusion that soils located in the catena on summit and shoulder positions, have vertical texture distribution formed primarily by lessivage process. Sandy texture of eluvial horizons noted in the Retisol of the slope pediment can be a consequence of not only lessivage but also of slope forming processes that led to the appearance of lithic discontinuity. The cluster analysis using Ward's method and 1-rPearson as the distance measure can be helpful for identification the lithogenic uniformity and/or non-uniformity of soil parent material.
\end{abstract}

Keywords: Retisols, lithic discontinuity, catena

\section{INTRODUCTION}

One of the fundamental features of soil, determining its properties, is the texture. Determination of particle size distribution, including distinction of fractions of subfractions in certain horizons of soil profile is the main indicator of the genesis and taxonomy of a given soil and makes the basis for interpretation of the conditions of parent material deposition, its lithological uniformity or non-uniformity (Dobrzański et al. 1977, Kowalkowski and Borzyszkowski 1977, KoneckaBetley 1979, Prusinkiewicz and Proszek 1990, Polish Soil Classification 2011). Of particular importance is the vertical differentiation in the texture for Retisols inherited from glacial materials, that has been many times related not only to the lessivage process but also with lithogenesis (Prusinkiewicz and Kowalkowski 1964, Kowalkowski and Ludwikowska 1993, Zagórski 1995, 2003; Dąbkowska-Naskręt and Jaworska 1997, Switoniak 2006). That is why for Retisols a thorough analysis of particle size distribution should make the basis for evaluation of their properties, genesis and systematic classification.

The study presented in this paper is aimed at determination of genesis and variations in texture of selected Retisols formed from ground moraine glacial till of Leszno Phase of Vistulian glaciation. The particle size analysis was performed using the sedimentological indices (Folk and Ward 1957) and granulometric indices (Prusinkiewicz and Proszek 1990, IUSS Working Group WRB 2015).

\section{MATERIALS AND METHODS}

The study was carried out in the area of Granowo commune, on arable land in southern and central part of Poznan Lake District in the Opalenica Plain. The study area is located at about $38 \mathrm{~km}$ SE from Poznan (Fig. 1). The field work was carried out in two stages. In the first one the variation of soils was established by the method of scattered points (pits and boreholes) and then representative pedons were localised. In the second stage the "Granowo" transect of $1200 \mathrm{~m}$ in length was delineated. In 25 open pits along the transect and 4 pedons of the stationary measurements, the soil morphology was determined by identification of genetic and diagnostic horizons, boundaries between horizons, soil colour, structure, consistency, reaction with chloric acid and taxonomic classification of soils. Pedons of the stationary measurements were instrumented with moisture sensors and piezometer to measure the profile soil water content and the water table.

In terms of geomorphology, the Granowo transect runs through flat ground moraine originating from Leszno Phase of Vistulian glaciation (Krygowski 1953, 1961; Starkel 1987). The upland is cut with subglacial channels in which at present run the rivers Mogilnica and Struga Kamieniecka, flowing to the Warciańsko-Odrzańsk proglacial stream valley. The parent material of the soils in the study area is carbonate glacial till that has been decalcified and has sandy texture in upper layers. 

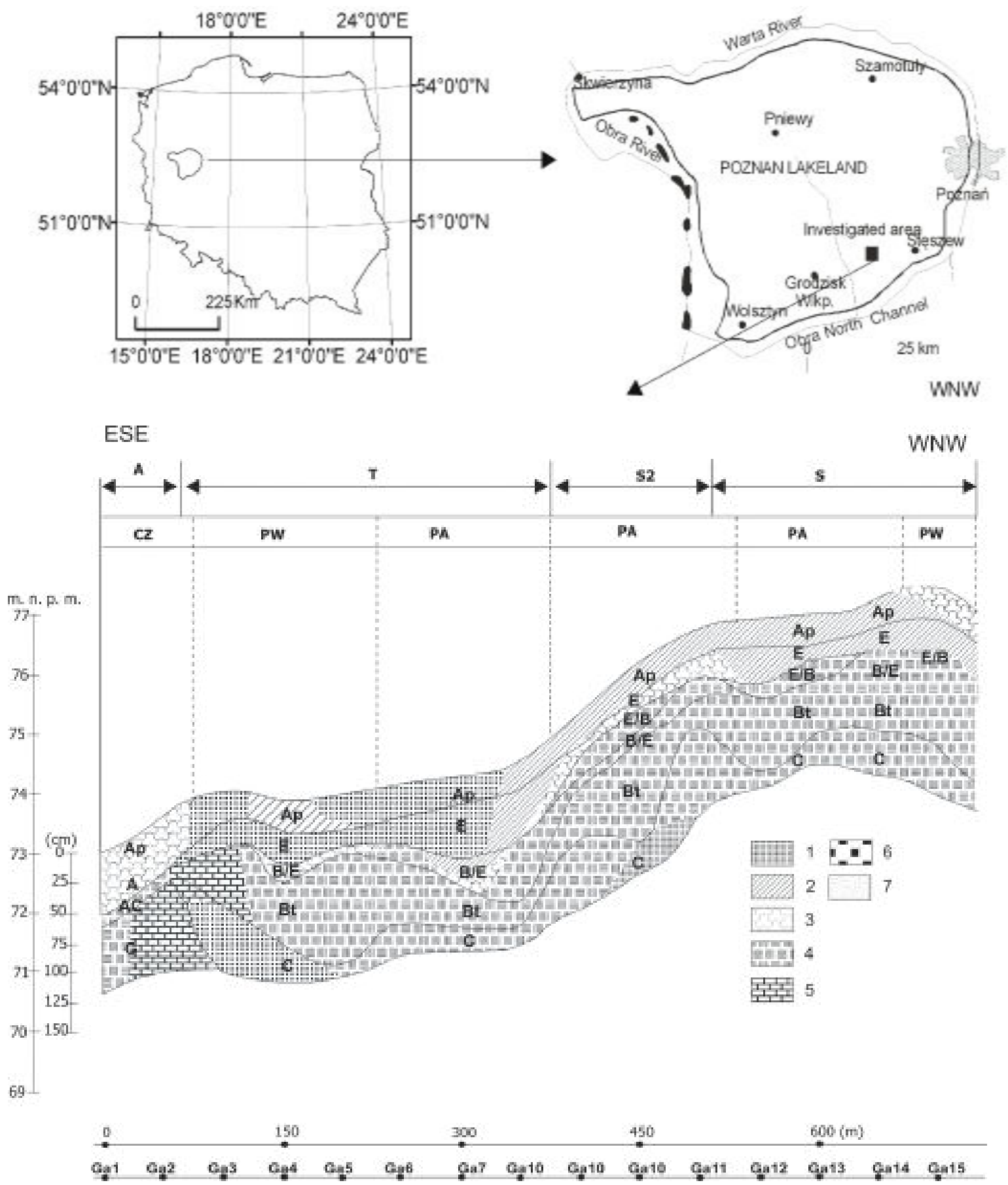

FIGURE 1. Location of investigated area and distribution of wells in the toposequence: $\mathrm{S}$ - summit, $\mathrm{S} 2$ - shoulder, T-pediment, A - footslope, CZ - Gleysols, PW - Luvisols, PA - Retisols; Texture Classes (According to PTG 2009): 1, 2 - sand, 3 - loamy sand, 4, 5- sandy loam, 6 - loam, 7 - sandy clay loam

In laboratory studies, the silt and clay fractions were determined by the aerometric method, according to the norm PN-R-04032 (1998), while the sand particles were distinguished by the sieve method with wet fractioning. The division into textural classes was made according to the PTG (2009).

The sedimentological indices and cumulative curves of soil particle size were determined by the procedure proposed by Folk and Ward (1957) expressing the particle diameters in the phi scale. The granulometric indices were calculated after Prusinkiewicz and Proszek (1990): A $-(0.25-0.1 \mathrm{~mm}) /(0.5-0.25 \mathrm{~mm}), \mathrm{B}-$ $(0.25-0.1 \mathrm{~mm}) /(1.0-0.5 \mathrm{~mm}) ; \mathrm{C}-(0.25-0.05 \mathrm{~mm}) /$ $(0.5-0.25 \mathrm{~mm}) ; \mathrm{D}-(0.25-0.02 \mathrm{~mm}) /(1.0-0.25 \mathrm{~mm})$; $\mathrm{E}-(0.5-0.05 \mathrm{~mm}) /(1.0-0.5 \mathrm{~mm})$. In order to identify the primarily non-uniformity of the soil parent material, 
the criteria referring to granulometric indices proposed by IUSS Working Group WRB (2015) were applied. Lithic discontinuities were identified if (i) the difference in the ratio of coarse to medium sand between two layers reaches at least $25 \%$ and the absolute difference in the content of coarse and/or medium sand between them is at least of $5 \%$, or (ii) if the difference in the ratio of coarse to fine sand between two layers reaches at least $25 \%$ and the absolute difference in the content of coarse and/or fine sand is at least of $5 \%$, or (iii) if the difference in the ratio of medium to fine sand between two layers is at least of $25 \%$ and the absolute difference in the content of medium and/or fine sand is at least of 5\%.

To evaluate the degree of similarity or difference in the particle size distribution in the sand separate, the cluster analysis using Ward's method and 1-rPearson as a distance measure was used. The paper presents results of laboratory determination of particle size distribution and granulometric indices calculated for four representative Retisols profiles: Ga14, Ga12, Ga10 and Ga6 (Fig. 1).

\section{RESULTS AND DISCUSSION}

The pedons analysed were labelled as Ga14, Ga12, Ga10 and Ga6 and classified as Eutric Albic Glossic Retisol (Abruptic, Epiarenic, Endoloamic, Aric, Cutanic, Ochric) (gleba płowa zaciekowa typowa acc. PSC 2011) - Ga14 and Ga10, Eutric Albic Glossic Retisol (Abruptic, Arenic, Aric, Cutanic, Ochric) (gleba płowa zaciekowa spiaszczona acc. PSC 2011) - Ga12, and Eutric Albic Glossic Endogleyic Retisols (Abruptic, Epiarenic, Endoloamic, Aric, Cutanic, Ochric) (gleba płowa zaciekowa spiaszczona ,z cechami gruntowego oglejenia" acc. PSC 2011) - Ga6. The soils studied showed well-developed eluvial horizons, which in profiles Ga14, Ga12 and Ga10 show the texture of loamy sands, while in pedon $\mathrm{Ga} 6$ - the texture of fine sands. The horizons with albeluvic glossae properties and the argic horizon that lie below the abovementioned eluvial horizons, usually show sandy loam texture. The boundary between the eluvial sandy horizons and clay illuvial ones was observed in the form of tongue-shaped patches of $\mathrm{E}$ horizon into $\mathrm{Bt}$

TABLE 1. Particle size distribution of analyzed soils

\begin{tabular}{|c|c|c|c|c|c|c|c|c|c|c|c|c|}
\hline \multirow{2}{*}{$\begin{array}{l}\text { Hori- } \\
\text { zon }\end{array}$} & \multirow{2}{*}{$\begin{array}{l}\text { Depth } \\
\text { (cm) }\end{array}$} & \multicolumn{9}{|c|}{ Percentage of soil fraction at diameter in $\mathrm{mm}$} & \multicolumn{2}{|c|}{ Texture class } \\
\hline & & $2-1$ & $1-0.5$ & $0.5-0.25$ & $0.25-0.1$ & $0.1-0.05$ & $0.05-0.02$ & $0.02-0.005$ & $0.005-0.002$ & $<0.002$ & PTG & USDA \\
\hline \multicolumn{13}{|l|}{ Ga14 } \\
\hline Ap & $0-28$ & 1.9 & 7.5 & 18.5 & 43.1 & 12 & 6 & 6 & 5 & 0 & pgdr & LS \\
\hline $\mathrm{E}$ & $28-43$ & 3.3 & 8.5 & 16.4 & 44.8 & 10 & 6 & 7 & 4 & 0 & pgdr & LS \\
\hline $\mathrm{B} / \mathrm{E}$ & $43-80$ & 1.2 & 8.4 & 16.2 & 37.2 & 11 & 4 & 8 & 4 & 10 & gpdr & FSL \\
\hline $\mathrm{Bt}$ & $80-110$ & 1.1 & 6 & 13.7 & 39.2 & 10 & 5 & 8 & 0 & 17 & gpdr & FSL \\
\hline $\mathrm{C} 1$ & $110-155$ & 1.5 & 5.8 & 12.4 & 36.3 & 12 & 7 & 7 & 4 & 14 & gpdr & FSL \\
\hline $\mathrm{Ck} 2$ & $155-$ & 1.5 & 6.1 & 12.7 & 39.7 & 10 & 5 & 11 & 3 & 11 & gpdr & FSL \\
\hline \multicolumn{13}{|l|}{ Ga12 } \\
\hline $\mathrm{Ap}$ & $0-25$ & 1.3 & 8 & 17.3 & 47.4 & 10 & 6 & 6 & 4 & 0 & pgdr & LS \\
\hline E1 & $25-40$ & 1.2 & 7.4 & 19.2 & 44.2 & 12 & 6 & 5 & 5 & 0 & pgdr & LS \\
\hline E2 & $40-58$ & 0.9 & 8 & 17.4 & 46.7 & 10 & 7 & 5 & 5 & 0 & pgdr & LS \\
\hline $\mathrm{E} / \mathrm{B}$ & $58-70$ & 1.2 & 6.8 & 17 & 43 & 10 & 7 & 5 & 5 & 5 & pgdr & LS \\
\hline $\mathrm{B} / \mathrm{E}$ & $70-100$ & 2.1 & 6.9 & 13.9 & 33.1 & 12 & 6 & 7 & 4 & 15 & gpdr & FSL \\
\hline $\mathrm{Bt}$ & $100-130$ & 2.4 & 6.1 & 11.3 & 37.2 & 6 & 7 & 8 & 5 & 17 & $\mathrm{gl}$ & FSL \\
\hline \multicolumn{13}{|l|}{ Ga10 } \\
\hline$\overline{A p}$ & $0-28$ & 0.7 & 7.8 & 17.6 & 48.9 & 9 & 6 & 5 & 5 & 0 & pgdr & LS \\
\hline E & $28-37$ & 1.3 & 7.6 & 16.1 & 43 & 12 & 5 & 8 & 6 & 1 & pgdr & LS \\
\hline $\mathrm{E} / \mathrm{B}$ & $37-58$ & 1.8 & 7.2 & 14.8 & 41.2 & 8 & 12 & 5 & 4 & 6 & gpdr & FSL \\
\hline $\mathrm{B} / \mathrm{E}$ & $58-65$ & 1.6 & 5.4 & 12.2 & 34.8 & 13 & 5 & 8 & 4 & 16 & gpdr & FSL \\
\hline Bt1 & $65-100$ & 1.5 & 5.9 & 12.5 & 37.1 & 11 & 6 & 8 & 3 & 15 & gpdr & FSL \\
\hline $\mathrm{Bt} 2$ & $100-150$ & 1.5 & 5.8 & 12.4 & 38.3 & 11 & 6 & 8 & 4 & 13 & gpdr & SL \\
\hline \multicolumn{13}{|l|}{ Ga6 } \\
\hline Ap & $0-28$ & 0.9 & 13 & 28 & 41.1 & 9 & 3 & 3 & 1 & 1 & pldr & $\mathrm{S}$ \\
\hline E & $29-50$ & 1.2 & 9.4 & 31 & 41.4 & 9 & 4 & 4 & 0 & 0 & pldr & $\mathrm{S}$ \\
\hline $2 \mathrm{~B} / \mathrm{E}$ & $50-65$ & 1.4 & 6.3 & 14.3 & 40 & 10 & 5 & 10 & 2 & 11 & gpdr & FSL \\
\hline 2Btg & $65-115$ & 1.1 & 5.7 & 13.3 & 34.9 & 13 & 7 & 6 & 3 & 16 & gpdr & FSL \\
\hline $2 \mathrm{Cg}$ & $115-130$ & 1.2 & 5.4 & 12 & 36.4 & 13 & 6 & 11 & 2 & 13 & gpdr & FSL \\
\hline
\end{tabular}

Explanation: pldr - piasek luźny drobnoziarnisty, pgdr - piasek gliniasty drobnoziarnisty, gpdr - glina drobnopiaszczysta, gl - glina lekka, $\mathrm{S}$ - sand, LS - loamy sand, FSL - fine sandy loam, SL - sandy loam. 
one, leasing to development of a albeluvic glossae properties (Bouma et al. 1968, Spiridonova et al. 1999). After Thoms (1993), Frederick et al. (2002) and Soil Survey Staff (2010), the abrupt smooth or wavy boundary change appearing between eluvial and illuvial horizons can be related to lithological heterogenity of the soil parent material.

The particle size composition of the Retisols studied shows the domination of sand fraction whose content in the eluvial horizons in soils of Ga14, Ga12 and Ga10 varies from 80 to $84 \%$, while in Ga6 soil it reaches $92 \%$ (Table 1). The fine sand is dominant and the second most abundant is medium sand. In the profile distribution of the sand particle-size classes in Ga14, Ga12 and Ga10 no significant differences were noted between the horizons. Only in the Ga6 a significant difference in the content of medium sand was apparent. In the eluvial horizons of this pedon the medium sand content varied from 28 to $31 \%$, while in deeper horizons it varied from 12 to $14.3 \%$, which can indicate the profile non-uniformity of the parent material. This observation is confirmed by the profile distribution of silt fraction, whose content in eluvial horizons was $7-8 \%$, while in deeper horizons it was
$16-19 \%$. In the pedons localised higher in the relief, the profile differences in the content of silt separate were not so much pronounced as in Ga6 soil (Table 1). The content of clay fraction did not exceed $1 \%$ in the eluvial horizons of the soil studied, but in the deeper illuvial horizons the content of this fraction varied from 11 to $17 \%$.

The Retisols studied showed poor sorting of mineral material of eluvial horizons whose segregation coefficient (GSO) varied from 1.77 to 2.14 in pedons Ga14, Ga12, Ga10, while in pedon Ga6 this coefficient varied from 1.31 to 1.40 . The deeper horizons were characterised by very poor (E/B horizon) or extremely poor sorting of soil material, which can be related to primeval uniformity of the parent material. According to Prusinkiewicz and Proszek (1990), as well as Zagórski (1996) poor, very poor or extremely poor sorting is characteristic feature of glacial till. Commonly observed for Retisols is the profile variation in GSO, evident when comparing the values for eluvial horizons (A and E) with illuvial ones or parent materials. The GSO values indicate a slightly better sorting of eluvial horizons in which the mean grain diameter $d$ varies from 0.109 to $0.209 \mathrm{~mm}$, while in the deeper argic horizon
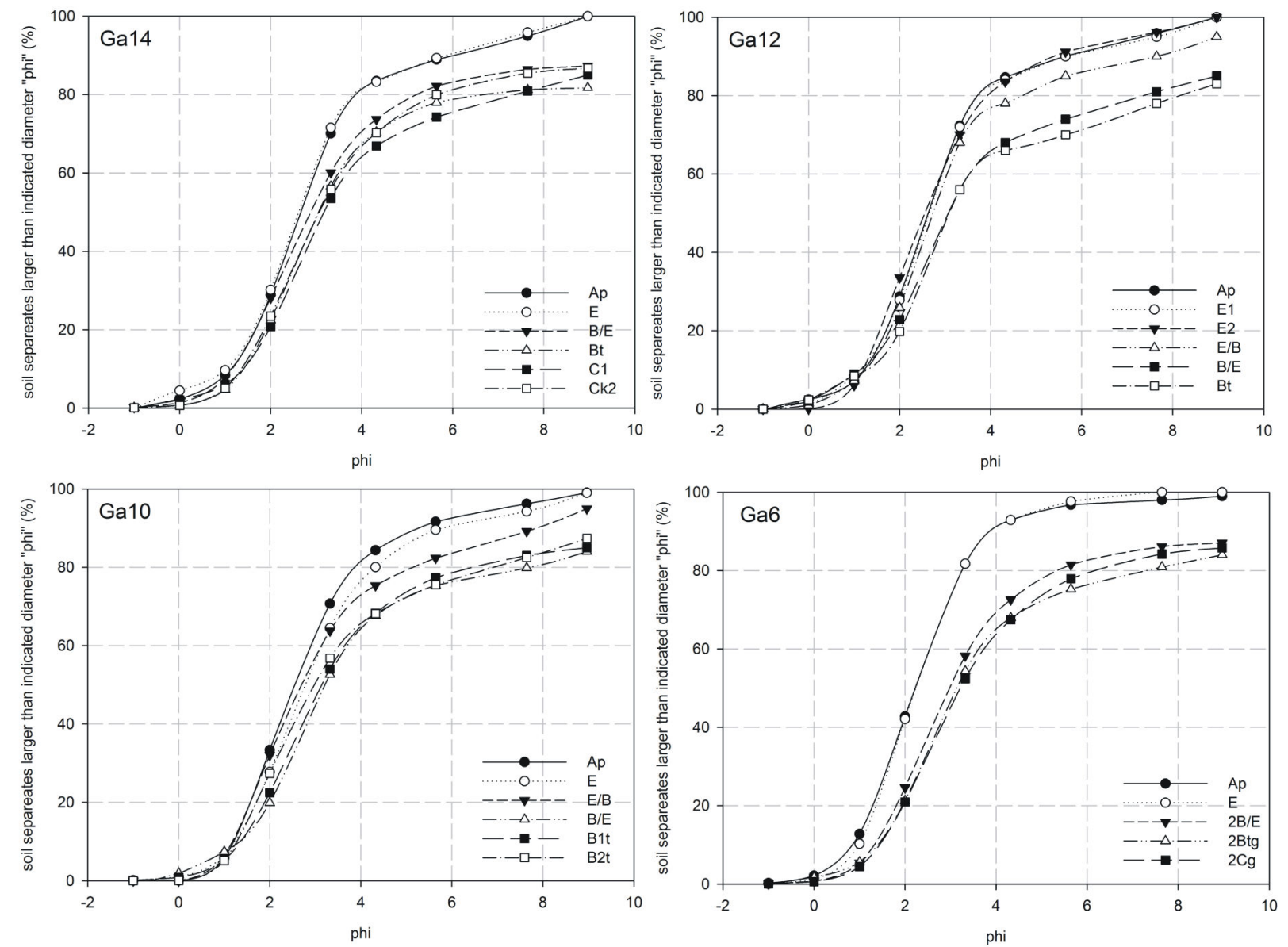

FIGURE 2. Cumulative texture curves of investigated soils 
the diameter $d$ varies from 0.023 to $0.053 \mathrm{~mm}$. It is related to the accumulation in illuvial horizons of fine fractions washed out from higher eluvial horizons in the process of lessivage. A confirmation of this interpretation can be the different shape of cumulative texture curves for these horizons (Fig. 2). In eluvial horizons, the cumulative texture curves are leptokurtic (Ga6) (GSP:1.26-1,31) or very leptokurtic (Ga12, Ga10, Ga14) (GSP:1.63-1.21) while for the argic diagnostic horizon this distribution is extremely leptokurtic (GSP:3.46-4:63). These profile differences in particle size distribution in Retisols is often interpreted as a result of not only pedogenesis but also lithogenesis (Baraniecka and Konecka-Betley 1993, Kowalkowski and Ludwikowska 1993, Świtoniak 2008). Therefore, often granulometric indices are used for identification of the profile diversity of parent material (Zagórski 1996).

Table 2 and Figure 3 present the granulometric indices determined for the soils studied. In the ground moraine upland soil analysed (Ga14), there are no significant differences in the values of A, B and C indices between horizons. Only the values of $\mathrm{D}$ and

TABLE 2. Sedimentological indices of analyzed soils

\begin{tabular}{lcccccc}
\hline Horizon & $\begin{array}{c}\text { Depth } \\
\text { [cm] }\end{array}$ & GSS & GSO & GSK & GSP & $\begin{array}{l}d \\
{[\mathrm{~mm}]}\end{array}$ \\
\hline Ga14 & & & & & & \\
\hline Ap & $0-28$ & 2.86 & 1.89 & 0.27 & 1.64 & 0.138 \\
E & $28-43$ & 2.81 & 1.91 & 0.24 & 1.71 & 0.143 \\
B/E & $43-80$ & 3.80 & 6.07 & 0.67 & 4.64 & 0.072 \\
Bt & $80-110$ & 5.40 & 8.46 & 0.81 & 4.63 & 0.024 \\
C1 & $110-155$ & 4.50 & 7.46 & 0.72 & 4.16 & 0.044 \\
Ck2 & $155-$ & 3.98 & 6.33 & 0.69 & 3.82 & 0.063 \\
\hline Ga12 & & & & & & \\
\hline Ap & $0-25$ & 2.79 & 1.77 & 0.25 & 1.85 & 0.145 \\
E1 & $25-40$ & 2.79 & 1.81 & 0.26 & 1.70 & 0.145 \\
E2 & $40-58$ & 2.86 & 1.86 & 0.30 & 1.94 & 0.138 \\
E/B & $58-70$ & 3.23 & 2.26 & 0.42 & 1.65 & 0.107 \\
B/E & $70-100$ & 4.41 & 7.54 & 0.71 & 4.05 & 0.047 \\
Bt & $100-130$ & 5.43 & 8.49 & 0.79 & 3.46 & 0.023 \\
\hline Ga10 & & & & & & \\
\hline Ap & $0-28$ & 2.80 & 1.80 & 0.28 & 2.10 & 0.144 \\
E & $28-37$ & 3.20 & 2.14 & 0.36 & 1.63 & 0.109 \\
E/B & $37-58$ & 3.28 & 3.42 & 0.51 & 2.60 & 0.103 \\
B/E & $58-65$ & 4.63 & 7.67 & 0.74 & 3.80 & 0.041 \\
Bt1 & $65-100$ & 4.43 & 7.44 & 0.73 & 4.17 & 0.047 \\
Bt2 & $100-150$ & 4.24 & 6.95 & 0.72 & 4.21 & 0.053 \\
\hline Ga6 & & & & & & \\
\hline Ap & $0-28$ & 2.26 & 1.40 & 0.13 & 1.31 & 0.209 \\
E & $29-50$ & 2.29 & 1.31 & 0.14 & 1.26 & 0.204 \\
2B/E & $50-65$ & 3.85 & 6.29 & 0.68 & 4.42 & 0.069 \\
2Btg & $65-115$ & 4.60 & 7.68 & 0.74 & 4.58 & 0.041 \\
2Cg & $115-130$ & 4.13 & 6.79 & 0.69 & 4.04 & 0.057 \\
\hline
\end{tabular}

Explanation: GSS - average particle size, GSO - standard deviation, GSK - skewness, GSP - kurtosis.
E indices are slightly lower in eluvial horizons than in the deeper argic horizon. This small diversity does not justify a conclusion about different genesis of eluvial and illuvial deposits. This observation is confirmed by the results of application of the above defined criteria consistent with those of the IUSS Working Group WRB (2015). In Ga12 and Ga10 soils no significant differences in granulometric indices across the profile were noted. Also the application of IUSS Working Group WRB (2015) criterion on the contributions of sand particle-size classes did not permit identification of non-uniformity of the parent material. On the basis of the results obtained it can be concluded that in the Retisols studied Ga14, Ga12 and Ga10, the mineral materials were diversified mainly in the process of lessivage into the sand eluvial part and the deeper illuvial part with accumulated clay fraction. Similar results have been obtained by Marcinek and Wiślańska (1984), Komisarek (2000) and Komisarek and Szałata (2008). In the profile Ga6 the granulometric index A took the values of 1.47 and 1.37, at the Ap and $\mathrm{E}$ horizons, respectively, while in deeper horizons the values of this index varied in the range 2.63-3.04. The distribution of $\mathrm{B}, \mathrm{C}$ and $\mathrm{D}$ indices across the profile was similar. From these data it can be concluded that within the pediment of the ESE exposition slope there are Retisols with lithic discontinuity separating the sandy eluvial zone from deeper illuvial horizon. This conclusion is corroborated by the values of granulometric indices used by IUSS Working Group WRB (2015). Significant differences were noted in the content of medium sand, which was $28 \%$ and $31 \%$ in Ap and E horizons, respectively, while in deeper horizons this content varied from 12 to $14 \%$. The smaller GSO values in the eluvial horizons of Retisol in Ga6 than those determined for Ga14, Ga12 and Ga10, indicate a slightly better sorting and longer deposition path of the surface deposits of the slope pediment than those for the material deposited in higher parts of the slope. These differences should be related to slope formation processes in which the material transport was very short, while the deposition was rapid and of poor segregation (Smolska 2008, Mycielska-Dowgiałło and Ludwikowska-Kędzia 2011).

Within Retisols of this slope pediment, lithic discontinuities were also observed (Kozłowski 2007).

Figure 4 presents results of the cluster analysis. This method permits determination of differences in the character of the frequency curves of particle size distribution for the sand fraction between different horizons and thus can be used as identification of lithic discontinuities. As follows from the data obtained, in Ga6 profile the eluvial Ap and E horizons show the particle size distribution in sand fraction different from 

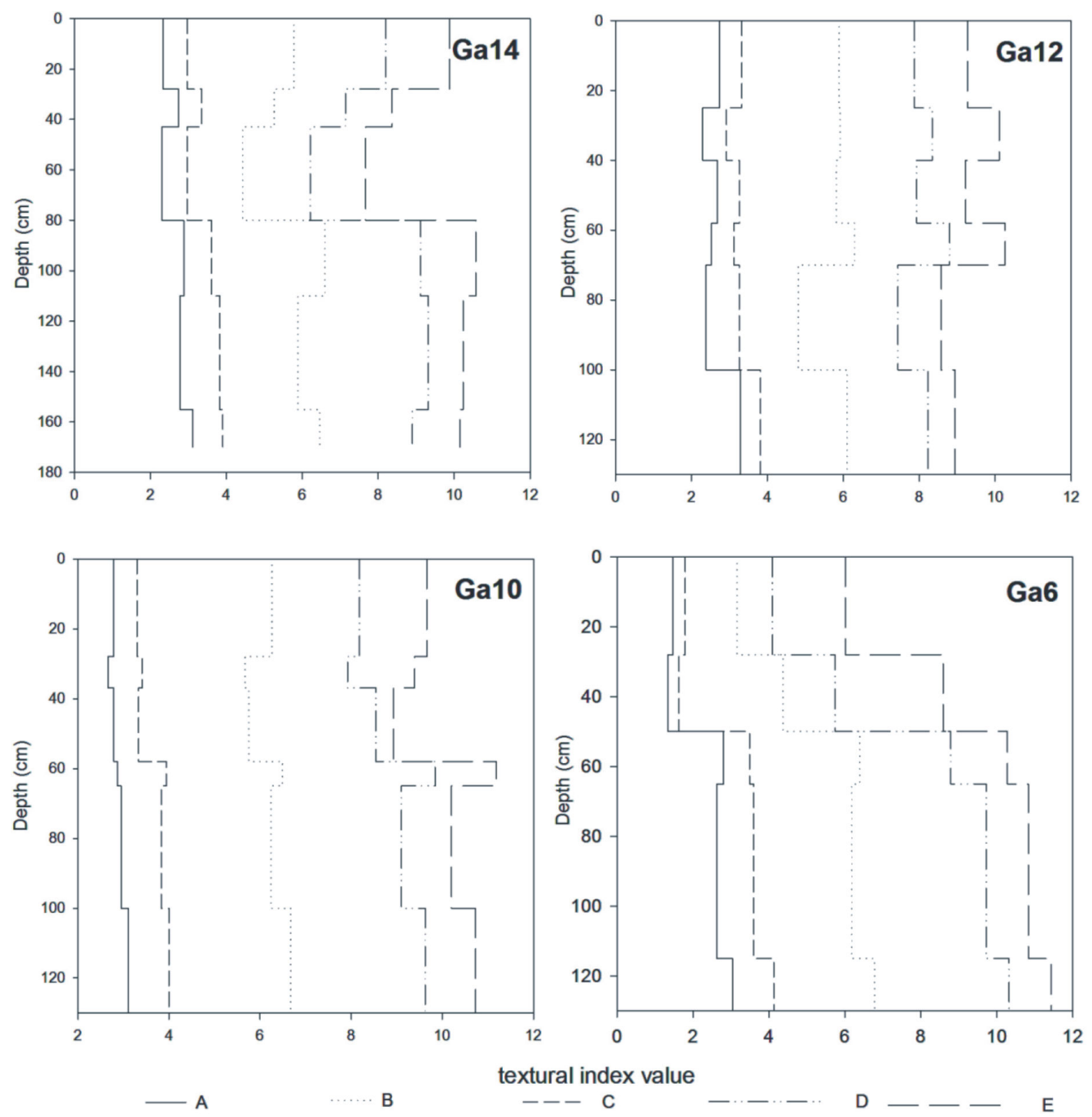

FIGURE 3. Granulometric indices of analyzed soils

those obtained for deeper horizons. The distance between two clusters, one made of Ap and E and the other comprising $2 \mathrm{Btg}$ and $2 \mathrm{Cg}$ exceeds 0.21 , which means that the correlation coefficient of particle size distribution in the sand fraction is close to 0.79 . For the Retisols in Ga14, Ga12 and Ga10 profiles, the differences in particle size distributions in the sand fraction between different horizons or clusters of horizons do not exceed 0.02 of the measure applied. Results of the Ward clustering confirmed that the profile differences in particle size distribution in Retisols is mainly a result of translocation of the finest particles from the eluvial horizons to illuvial ones (Marcinek and Wiślańska 1984, Komisarek 2000, Komisarek and Szałata 2008), although in the pedons studied an abrupt change in particle size distribution is found. This interpretation is in agreement with the results reported by Ahr et al. $(2012,2013)$ for sandy mantle Alfisols of the Texas Gulf Coastal Plain.

\section{CONCLUSIONS}

1. The Retisols studied show similar degree of soil material segregation which is characteristic of typical glacial till.

2. The vertical differences in particle size distribution and granulometric indices, confirmed the dominant contribution of the process of lessivage in development of textural vertical contrast of Retisols located on summit and shoulder catenal positions.

3. Sandy texture of eluvial horizons noted in the Retisol of the slope pediment can be a consequence of not only lessivage but also of slope forming processes that led to the appearance of lithic discontinuity. 

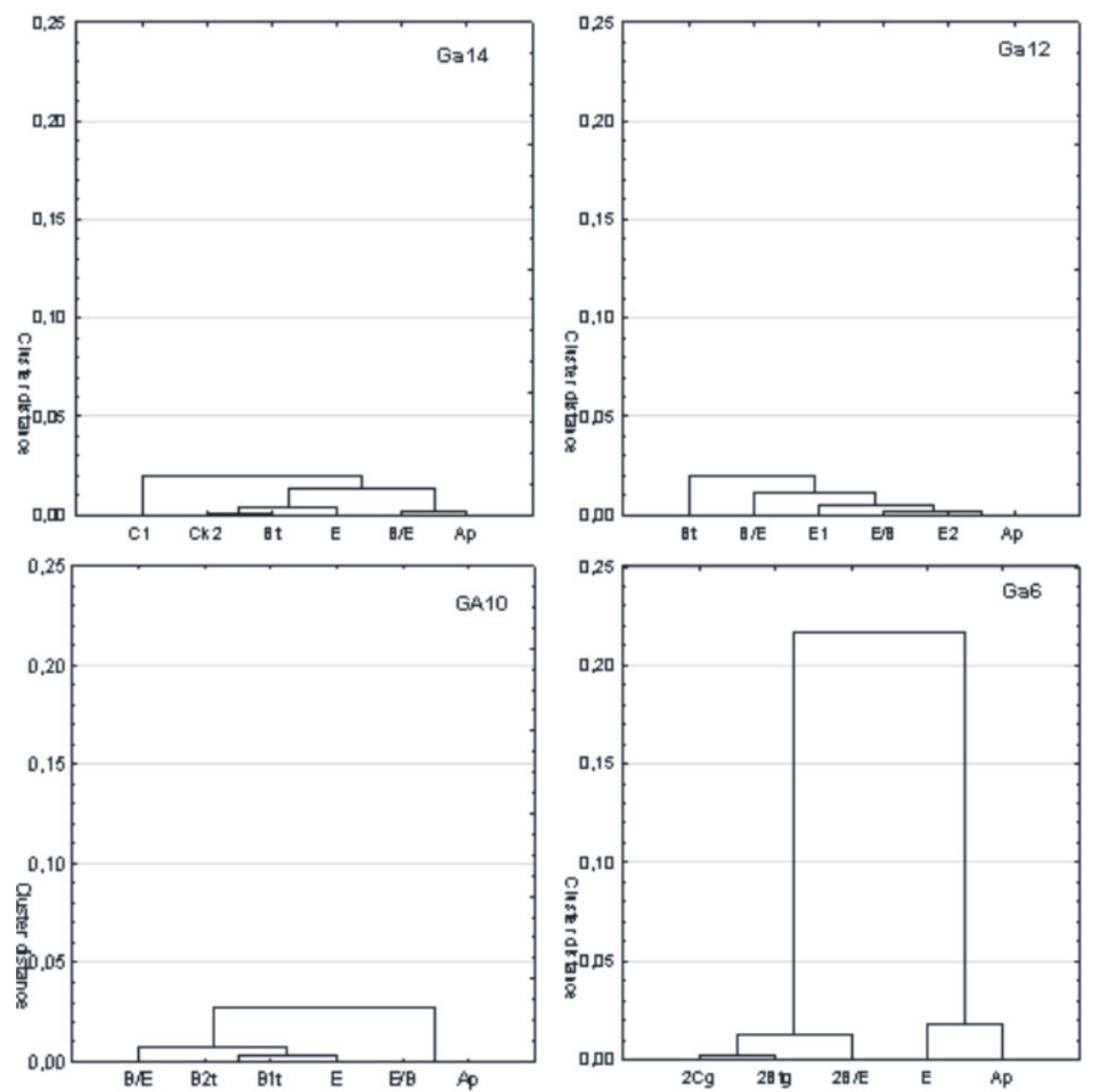

FIGURE 4. Dendrograms of hierarchical cluster analysis of sand fraction

4. The cluster analysis using Ward's method and 1 -rPearson as the distance measure can be helpful for identification the lithogenic uniformity and/or non-uniformity of soil parent material.

\section{REFERENCES}

Ahr S.W., Nordt L.C., Driese S.G., 2012. Assessing lithologic discontinuities and parent material uniformity within the Texas sandy mantle and implications for archaeological burial and preservation potential in upland settings. Quaternary Research 78: 60-71.

Ahr S.W., Nordt L.C., Forman S.L., 2013. Soil genesis, optical dating, and geoarchaeological evaluation of two upland Alfisol pedons within the Tertiary Gulf Coastal Plain. Geoderma 192: 211-226.

Baraniecka M.D., Konecka-Betley K., 1993. Zmiany litologiczne i pedologiczne $\mathrm{w}$ glinach zwałowych zlodowacenia warty $\mathrm{w}$ kopalni Bełchatów. Acta Geographica Lodziensia 65: 19-33.

Bouma J., Pons L.J., Van Schnylenborgh J., 1968. On soil genesis in temperate humid climate: VI The formation of Glossudalf in loess. Netherlands Journal of Agricultural Science 16: 58-70.
Dąbkowska-Naskręt H., Jaworska H., 1997. Gleby płowe wytworzone z utworów pyłowych Pojezierza Chełmińsko-Dobrzyńskiego i Wysoczyzny Kaliskiej. Część II. Badania litologicznej jednorodności na podstawie analizy uziarnienia. Roczniki Gleboznawcze 48(3/4): 123-136.

Dobrzański B., Konecka-Betley K., Czępińska-Kamińska D., 1977. Procesy kształtowania się gleb wytworzonych z gliny zwałowej Wysoczyzny Siedleckiej. Zeszyty Naukowe SGGW-AR w Warszawie, Rol. 16: 9-24.

Folk R.L., Ward W.C., 1957. Brazos river bar: a study in the significance of grain size parameters. Journal of Sedimentary Petrology 27(1): 3-26.

Frederick C.D., Bateman M.D., Rogers R., 2002. Evidence for eolian deposition in the sandy uplands of East Texas and implications for archaeological site integrity. Geoarchaeology 17(2):191-217.

IUSS Working Group WRB, 2015. World reference base for soil resources 2014, update 2015 international soil classification system for naming soils and creating legends for soil maps. World Soil Resources Reports no. 106. Rome: FAO

Komisarek J., Szałata S., 2008. Zróżnicowanie uziarnienia w profilach gleb płowych zaciekowych z obszaru Wielkopolski. Nauka Przyroda Technologie 2, 2, \#10. 
Komisarek J., 2000. Kształtowanie się właściwości gleb płowych i czarnych ziem oraz chemizmu wód gruntowych w katenie falistej Pojezierza Poznańskiego. Rozprawy Naukowe Zeszyt 307, Roczniki Akademii Rolniczej w Poznaniu.

Konecka-Betley K., 1979. Reliktowe procesy glebotwórcze w glebach współczesnych wytworzonych z gliny zwałowej. Zeszyty Naukowe SGGW-AR w Warszawie, Rol. 18: 77-95.

Kowalkowski A., Ludwikowska M., 1993. Katena gleb na południowym stoku Góry Plebańskiej w zlewni rzeki Bobrzyczki. Kieleckie Towarzystwo Naukowe, Monitoring Środowiska Regionu Świętokrzyskiego 1: 101-108.

Kowalkowski A., Borzyszkowski J., 1977. The role of periglacial and extraperiglacial perstruction in the formation of the soil profile in Central Europa. Folia Quaternaria 49: 25-37.

Kozłowski M., 2007. Reżim wodny gleb i chemizm wód gruntowych w układach katenalnych Pojezierza Poznańskiego. Maszynopis Katedry Gleboznawstwa i Rekultywacji, Poznań.

Krygowski B., 1953. Mapa geomorfologiczna Niziny Wielkopolskiej. Red. B. Krygowski.

Krygowski B., 1961. Geografia fizyczna Niziny Wielkopolskiej. Cz. 1. Geomorfologia. PTPN, Poznań.

Marcinek J., Wiślańska A., 1984. Asocjacje czarnych ziem i gleb płowych falistej moreny dennej Równiny Kościańskiej. Roczniki Akademii Rolniczej w Poznaniu 149 (5): 65-81.

Mycielska-Dowgiałło E., Ludwikowska-Kędzia M., 2011. Alternative interpretations of grain-size data from Quaternary deposits. Geologos 17(4): 189-203.

PN-R-04032. 1998. Gleby i utwory mineralne. Pobierania próbek i oznaczanie składu granulometrycznego. Polski Komitet Normalizacyjny, Warszawa.

Polish Soil Classification (Systematyka gleb Polski), 2011. Roczniki Gleboznawcze - Soil Science Annual 62(3): 1-193.

Polskie Towarzystwo Gleboznawcze, 2009. Particle size distribution and textural classes of soils and mineral materials classification of Polish Society of Soil Science 2008. Roczniki Gleboznawcze - Soil Science Annual 60(2): 5-16.

Prusinkiewicz Z., Kowalkowski A., 1964. Studia gleboznawcze w Białowieskim Parku Narodowym. Roczniki Gleboznawcze - Soil Science Annual 14(2): 161-305.

Prusinkiewicz Z., Proszek P., 1990. Program komputerowej interpretacji wyników analizy uziarnienia gleb - TEKSTURA. Roczniki Gleboznawcze - Soil Science Annual 40(3/4): 5-16.

Smolska E., 2008. Badania sedymentologiczne współczesnych osadów deluwialnych $\mathrm{i}$ ich znaczenie w ocenie dynamiki procesów erozji gleby na przykładzie Pojezierza Suwalskiego.
Przeglad Naukowy. Inżynieria i Kształtowanie Srodowiska 17(2): 202-212.

Soil Survey Staff, 2010. Keys to Soil Taxonomy, 11th edition. U.S. Department of Agriculture, Natural Resources Conservation Service, Washington D.C.

Spiridonova I.A., Sedov C.N., Blonnikova M.A., Targuljan V.O., 1999. Organizacija, sostav i genezis osvetlennych člementov stroenija dernovo-podzolistych suglinistych počv. Genezis i geografija počv. Počvovedenie 5: 561-567.

Starkel L., 1987. Przeglądowa mapa geomorfologiczna Polski (1:500 000). Instytut Geografii i Przestrzennego Zagospodarowania PAN. Warszawa.

Świtoniak M., 2006. Litologiczne uwarunkowania kierunku rozwoju procesów glebotwórczych w glebach o dwudzielnym uziarnieniu na terenie Pojezierza Brodnickiego. [W:] Dokumentacja Geograficzna nr 32 ,Idee i praktyczny uniwersalizm geografii" - Geografia fizyczna (red. P. Gierszewski, M.T. Karasiewicz), IGiPZ PAN, Warszawa: 278-285.

Świtoniak M., 2008. Classification of young glacial soils with vertical texture-contrast using WRB system. Agrochimija i Gruntoznawstwo 69, Charkiw: 96-101.

Thoms A.V. (Ed.), 1993. The Brazos Valley Slopes Archaeological Project: Cultural Resources Assessments for the Texas A\&M University Animal Science Teaching and Research Complex, Brazos County, Texas.: Archaeological Research Laboratory, Reports of Investigations 14. Texas A\&M University, College Station.

Zagórski Z., 1995. Mikromorfologiczne cechy procesów litoi pedogenezy w glebach niejednorodnych wytworzonych z osadów glacjalnych. Roczniki Gleboznawcze - Soil Science Annual 46(3/4): 71-93.

Zagórski Z., 1996. Granulometryczne wskaźniki procesów pedoi litogenezy w glebach niejednorodnych wytworzonych z osadów glacjalnych. Roczniki Gleboznawcze - Soil Science Annual 47: 125-135.

Zagórski Z., 2003. Minerały pierwotne jako wskaźniki procesów lito- i pedogenezy w glebach niecałkowitych wytworzonych z osadów glacjalnych zlodowacenia Warty. Roczniki Gleboznawcze - Soil Science Annual 54(4): 45-56.

Received: October 20, 2016

Accepted: February 14, 2017

Associated editor: J. Chojnicki

\section{Zróżnicowanie składu granulometrycznego w wybranych glebach płowych zaciekowych Równiny Opalenickiej}

Streszczenie: W pracy przedstawiono wyniki badań zróżnicowania uziarnienia w glebach płowych zaciekowych układu katenalnego Równiny Opalenickiej. Celem pracy było określenie genezy zróżnicowania składu granulometrycznego w wybranych glebach płowych zaciekowych wytworzonych z gliny zwałowej dennomorenowej zlodowacenia bałtyckiego fazy leszczyńskiej. Analizowane gleby płowoziemne cechują się słabym lub skrajnie słabym stopniem segregacji materiału glebowego, który charakterystyczny jest dla typowych glin morenowych. Uzyskane wyniki zróżnicowania składu granulometrycznego i wskaźników uziarnienia w profilach analizowanych gleb kulminacji i stoku swobodnego wyniesienia dennomorenowego, wskazują na główny udział procesu lessiważu w kształtowaniu się profilowego zróżnicowania składu granulometrycznego. Silne spiaszczenie poziomów eluwialnych w jednym profilu gleby płowej zaciekowej pedymentu stoku, może wynikać nie tylko z procesu lessiważu, ale także z procesów stokowych, które doprowadziły do powstania nieciągłości litologicznej. Analiza skupień metodą Worda z miarą odległości 1-rPearson może być pomocna przy identyfikacji jednorodności i/lub niejednorodności materiału glebowego.

Stowa kluczowe: gleby płowe zaciekowe, nieciągłość litologiczna, katena 